\title{
An Analysis of TABoo Words in DeadPoOL \\ Movie
}

\author{
Ririn Zevanya Purba ${ }^{1}$, Zainuddin ${ }^{2}$, \\ I WY DIRGEYASA ${ }^{3}$ \\ ${ }^{123}$ UNIVERSITAS NEGERI MEDAN
}

\begin{abstract}
The research dealt with taboo words in Deapool movie. The objectives of research aimed at explaining the types of taboo words and also to figure out motives of using taboo words in Deadpool movie. The research conducted by using descriptive qualitative method. This study was different from previous researcher that found types and function of taboo words while in this study focused on types and motives of using taboo words. The data were taken from the utterances that contain taboo words by first main character in this movie. There were 82 taboo words that had been uttered in this movie. From nine types of taboo words, there were eight of them, they were Cursing 2,44\%, Profanity 3,66\%, Obscenity 40,24\%, Vulgarity 6,10\%, Insults and slurs 9,76\%, Slang 12,20\%, Epithets 20,73\%, and Scatology 2,44\%. And for the motives of using taboo words, there were five from five motives of them, they were Angry or Frustration 30,48 \%, Descriptive- evaluative 43,90 \%, Joking 7,32\%, Surprise 14,64\%, and Sarcastic Irony Insults 3,66\%.
\end{abstract}

Keywords: taboo words, types of taboo words, motives of using taboo words, Deadpool-movie. 


\section{INTRODUCTION}

Language is an important tool for interaction and communication. In some societies there are a number of words that may not be spoken or approved. These words are called taboo. If taboo words are mentioned or spoken in the community, they will be considered rude.

Apart from our attitude about taboo language, it actually exists in our society, and very often occurs in several conversations in certain situations of society. Because of a social change, now legal sanctions are beginning to disappear and there is a more violent tendency that society has been more relaxed in accepting taboo words as part of communication. The existence of films in the community has a strong position among other communication media. Although many films have negative meanings and use the taboo words contained in them, people still enjoy them. The existence of films containing the word taboo can affect the community on their environment. Of course the impact is people use taboo words that come from movies that they have watched to be used when they make a short or long conversation with others. Most Indonesian people do not understand the meaning of taboo words in English when they speak to others. They just assume that English always sounds cool no matter what, even though the definition of the word is not good. They use taboo words to be considered cool when communicating with others. This is an issue that must be discussed so that people are getting better at sorting words that are appropriate to use when communicating.This is the reason researcher wants to use this case as a title.

One of movies that actively used utterances that contain taboo words in the conversations of its characters was Deadpool. The Deadpool movie told the story of a man named Wade Wilson who was a former member of a special army who left his old job and now worked as a mercenary or rather a paid bouncer. At one point, Wade was involved with super human experiments which resulted in him having a faster response and healing powers (like Wolverine). With his new strength, he tried to pursue someone who had destroyed his life.

The reason why researcher wanted to use this film as the object of this research was because it related to the topic of taboo words and each character in the film often used taboo and abusive words with each other.

In this research, the researcher tried to identify the types of taboo words used by Wade Wilson's character in Deadpool movie and the motives of using taboo words between Deadpool movie. Deadpool movie contained an action comedy genre where the story was very interesting and not only monotonous that serves violent acted but also interesting with funny scenes that made the atmosphere was not only terrified but also hilarious. 


\section{REVIEW OF LITERATURE}

\section{Taboo Words}

Jay (1992 : 4) stated that a taboo is roled to control or inhibit certain behavior, thoughts, or speech. Different cultures use taboos to control individuals within the group in order to preserve social order. The power or the strength of taboo is relative to the power of controlling group to sanction or to punish the perpetrator. The function of the taboo is to prohibit the behavior of a speaker and preserve social cohesion. The focus of taboo topic in society is on the speaker's behavior.

\section{Types of Taboo}

Taboo words in its usage, refer to several uses of offensive speech.Technically, speaking taboo words is usually wishing harm on a mental of person. According to Jay (1992:2 - 9) states that the use of taboo words is used comprehensively here to include categories such as cursing, profanity, blasphemy, obscenity, vulgarity, slang, epithets, insulting ethnic-racial slurs, and scatology.

\section{a. Cursing}

Cursing is used to cause harm to another person by using specific words or phrases. As a result of the group consensus, curse words gain the ability to cause harm through physical and psychological punishments.

\section{b. Profanity}

A religious distinction underpins profanity. To be profane means to be secular or to act outside of religious customs. To be profane is to be ignorant of or intolerant of the rules of a specific religious order. It is outside of the church's doctrines.

\section{c. Blasphemy}

A blasphemy is a religious or religious doctrine attack. Blasphemy is aimed squarely at the church. Blasphemy obtains scorn through the power of the church, such that the greater the power of the religious institution.

\section{d. Obscenity}

Obscenity is a legal term in this context. Obscenity laws are intended to protect listeners. To call a word obscene means that it cannot be used freely; it is restricted; and using such speech risks legal repercussions. Obscene words in American English are almost always sexual in nature The courts have deemed the sex act and related imagery to be so offensive that they cannot be freely uttered. Words with universal restriction include fuck, motherfucker, cocksucker, cunt, and tits.

\section{e. Vulgarity}

Vulgarity refers to the language of the common man, who is unsophisticated, unsocialized, or uneducated. Vulgarity serves no purpose or function other than to meet the basic 
communication needs of the average person. Vulgarisms are not necessarily obscene or taboo; they simply reflect the roughness of street language. Snot, bloody, up yours, booger, slut, piss, crap, kiss my ass, snatch, on the rag, puke are examples of vulgar words.

\section{f. Slang}

Slang is a growing vocabulary used for communication among certain subgroups (teenagers, musicians, soldiers, drug users, or athletes). Pimp, cherry, dweeb, bennies, cupcakes, jelly roll, jock, and other slang terms.

g. Epithets

Epithets are short, powerful bursts of emotional language. They are effective in terms of presentation (loudness or duration), for example, joking. Typically, the epithet is uttered in frustration. The epithet is uttered for a non-corrective purpose (as with targeted use), but primarily to reduce the speaker's anger level.

\section{h. Insult and Slurs}

Insults and slurs are verbal assaults on others. These words are spoken solely to cause harm to the other person. Slurs can be racial, ethnic, or social in nature, and they can reveal the speaker's stereotyping or prejudice. Insults are commonly heard on the school playground and can refer to the target's physical, mental, or psychological characteristics.

\section{i. Scatology}

Scatology refers to the study of feces and elimination. Because they are associated with disgusting items, scatological references are offensive. Different cultures place different emphasis on various types of taboo. Poo-poo, ka-ka, poop, turd, crap, shit, shit ass, shit for brains, piss, piss pot, piss off, far are scatological references to feces and elimination.

\section{Motive of Using Taboo Words}

\section{a. Anger and/or frustration}

Because it is difficult to distinguish between anger and frustration using language alone, these emotions are combined. When a boy's basketball field goal attempt was blocked, he responded, "What the fuck?" This is an example of anger-frustration. Surprisingly, the word fuck was only used to express anger or frustration.

\section{b. Descriptive - Evaluative}

Descriptive - Evaluative is used to show how speakers described the objects and events in the situation, either connotatively or denotatively. This game stinks is a baseball game evaluation, whereas "my sneakers are shitty" is a denotative description after stepping in dog feces. Taboo words also amplify descriptions; for example, he beat the hell out of him denotes the amount of physical energy expended in the fight. 


\section{c. Joking}

Joking is used in formal joke frames and in the use of taboo words in humor. To make jokes and stories as funny as possible, obscenities were sometimes added. Words like dick, gay, and penis were frequently used. The majority of these jokes were about body parts or sexually related processes (ass, balls, boobs,erection, hump, gay and wacking off).

d. Surprise

It is a reaction to unexpected success, loss, or other behavior. These are typical expletives, and they frequently include religious terms, such as Jesus! or oh God.

\section{e. Sarcastic Irony or Insults}

These include derogatory words and descriptions, such as you fag or scum face. Insults served the function of denoting undesirable qualities of the target, whether these were real or imagined by the speaker, rather than simply expressing anger on the part of the speaker.

\section{RESEARCH METHODOLOGY}

According to Ary (2018), the qualitative inquirer deals with data in the form of words or pictures rather than numbers and statistics. In this study, the descriptive method was used, which is a research method that attempts to describe and interpret objects in accordance with reality. Because the data analysis was presented in a descriptive manner, the descriptive method was used. The researcher used selected utterances or sentences from the first actor's character in the Deadpool film.

The source of data in this study was taken from the transcript dialogues of the Deadpool movie. This film was released on February 8, 2016 in Paris and on February 12, 2016 in the United States.

The data of this study were in form of words, phrases, clauses or sentences found in the dialogues of the first character of Deadpool movie. The transcript was not written by the character since she took it from the internet webs.

The data obtained are analyzed by using descriptive qualitative with the following steps: (1)Identifying each utterances that was uttered by the first character in this movie by using Jay's theory.(2)Classifying and listing data into the types and motives of using taboo words.(3)Tabulating and total number of each type and motive of using taboo words.(4)Determining and describing the most dominant type and motive of using taboo words in Deadpool movie.(5)Finding the percentage from each type and motive of using taboo words in Deadpool movie by using this formula:

$\mathrm{X}=$ The percentage of the type and motive of using taboo words

$\mathrm{F}=$ Frequency of type and motive of using taboo words

$\mathrm{N}=$ The total number of type and motive of using taboo words 


\section{FINDINGS AND DISCUSSIONS}

\section{Findings}

1. First, there were eight out of nine different types of taboo words in the Deadpool movie. They were Cursing ( 2 taboo words, 2,44 \%), Profanity ( 3 taboo words, 3,66 \%), Obscenity (33 taboo words, 40,24\%), Vulgarity (5 taboo words, 6,10 \%), Insults and slurs (8 taboo words, 9,76 \%), Slang (10 taboo words, 12,20 \%), Epithets (17 taboo words, 20,73 \%), and Scatology (2 taboo words, 2,44 $\%)$.

2. Second, there were five reasons for using taboo words in this film: rage or frustration, descriptiveevaluative, joking, surprise, and sarcastic irony and insults. There were 82 taboo words uttered by the first character in the first film, and they all had a reason to be used. There were 25 taboo words or $30,48 \%$ for angry or frustration, 36 taboo words or $43,90 \%$ for descriptive-evaluative, 6 taboo words or 7,32\% for joking, 12 taboo words or 14,64\% for surprise and 3 taboo words or 3,66 \% for sarcastic irony and insults.

\section{Discussions}

Trudgill (2000) stated that taboo words as things that are related to behavior that are supernaturally believed are prohibited or considered immoral and inappropriate. Taboo words occur in most languages and mistakes using them often make a person accept punishment or shame in public. Cursing, profanity, obscenity, vulgarity, insults and slurs, slang, epithets, and scatology are examples of taboo words used in this film by Jay (1992).

After analyzing the data, Obscenity type is the most used in these movies, however, Blasphemy type is never used at all. We know that obscenity is defined as a term that is characterized by crude sexual activity and bodily effluvia. Obscenity is thought to be illegal in public because it involves repulsion to the senses, is abhorrent, impolite, and detestable to morality. One of words contain obscenity is fuck. Word fuck is not always translated as sexual activity that is done by couple, it can be translated to be another definition based on context. Based on the data before, the most dominant of the usage word fuck is not to show that he wants to make a sexual activity but is used to express the first character's feelings in this movie, which is Deadpool towards the addressee.

A blasphemy is a religious or religious doctrine attack. Blasphemy is aimed squarely at the church. Blasphemy obtains scorn through the power of the church, such that the greater the power of the religious institution. In this movie, Blasphemy type is never pops up in this dialogue. As we know that using harsh words to mock another religion is such a sentimental issue that people want to make a far distance from it. Indeed, this movie contains many taboo words, but the writer in this movie doesn't use harsh words to mock any religion in this world. This indicates that this movie is still worth to watch for adults whose aim is to 
entertain the audience without having to offend the religion beliefs for the sake of mutual comfort. Thus, the genre of this movie is comedy and action that has no connection about religion stuff.

Then, according to Jay (1992), there are five reasons for using taboo words: anger or frustration, descriptive-evaluative, joking, surprise, and sarcastic irony and insults.

From the previous explanation in data analysis, Descriptive-evaluative motive is dominant in this movie, while sarcastic irony and insults is hardly to be used. This indicates that the motive of using taboo words is to describe all the utterances by using taboo words to persuade the message from the utterance to the addressee.

Sarcastic irony and insults from the motive of taboo words is used as derogatory words to mock body, physical, mental or everything that uttered to mock the addressee. But in this movie, the first character hardly use words whose motive to mock anyone else. It indicates that this movie has no motive to mock another characters for the sake of mutual comfort of the audience. The writer in this movie knows that there are so many shapes or characters from the audience, so he keeps the bad words that still good, and stay away from bad jokes to mock physical especially body. We know that lately body shaming is a new verbal crime. Using taboo words which motive relates body shaming is forbidden so that the audience don't feel bad, but feel happy because the motive of using taboo words is just for joking based on the context in this movie.

\section{CONCLUSIONS AND SUGGESTIONS}

\section{Conclusions}

The following are some of the conclusions that can be drawn from the research findings and discussion.

The study reveals that there are eight categories of taboo words practices found in this movie, which are cursing, profanity, obscenity, vulgarity, slang, epithets, insults and slurs, and scatology, in relation to

the first objective of this research, which is to identify and illuminate the types of taboo words in Deadpool movie.

The most dominant type is obscenity that shows that this movie to express the first character's feelings in this movie, which is Deadpool towards the addressee.

Blasphemy type is never used because the writer wont to offend any else religion in this worlds for the sake of mutual comfort.

And for the last objective of the research is finding motives of using taboo words in Deadpool movie. Researcher found there were five from five motives of using taboo words found in Deadpool movie, they were anger or frustration, descriptive-evaluative, joking, surprise, and sarcastic irony and insults. 
Descriptive-evaluative motive is dominant in this movie that indicates that the motive of using taboo words is to describe all the utterances by using taboo words to persuade the message from the utterance to the addressee.

On the other hand Sarcastic irony and insults is hardly to be used to keep audience' comfort for hearing all those bad words not to offend the physical, mental, shape, or everything from the movie that may offend audience's feelings.

\section{Suggestion}

Regarding to the conclusions of the research, the researcher postulates some suggestions for the following parties.

The first is for general readers; the researcher advises them to be more aware of the "bad" label of swearing. Saying a taboo word that has been labeled as bad language because of stigmatized expressions and their associations is not always bad. The study reveals the contradictory ideas in swearing; swearing is good when used correctly and in the right context.

The second is for aspiring scientists. Saying taboo words in a specific context is worth investigating, i.e. contradictory ideas in taboo words: taboo words are significantly tabooed for the stigmatized expressions that are forbidden in public discourse, but there are positive outcomes of taboo words such as saying taboo words as humor, saying taboo words as an emphasis marker, and saying taboo words as a solidarity signal that deserve special consideration. As a result, focusing on a specific topic of saying taboo words will allow the future researcher to be more focused and gain a more detailed understanding of swearing practices.

\section{REFERENCES}

Alan, Evision. 1995. Oxford Learner's Pocket Dictionary. New York: Oxford University Press. Allan, K et al. 2006. Forbidden Words: Taboo and the Censoring of Language. New York: Cambridge University Press.

Ary, Donald et al. 2018. Introduction to Research in Education (Tenth Edition). Canada: Wadsworth Publishing.

Baudin, Nurliyana. 2014. Swearing in English Among A Group of Female Malaysian Teenagers. International Journal of Contemporary Applied Sciences, 2308-1365

Crystal, David. 2003.English as a global language. Cambridge: Cambridge 
University Press. Creswell, John W. 2014. Research Design, Qualitatives, Quantitatives, and Mixed Methods Approches (Fourth Edition). United States of America: Sage Publications.

Holmes, J. 2001. An Introduction to Sociolinguistics. New York: Longman.

Iragihati, Emilia, Yasa and Febrianuswanioro. 2012. The Use of Taboo Words between Main Characters Seen in Conviction Movie. Malang. State University of Malang.

Jay, Timothy. 1992. Cursing in America : Study of Dirty Language in the Courts. Philadelphia : John Benjamins B.V, the Netherlands.

Ningjue, Zhou. 2010.Taboo Languages on the Internet: An Analysis of Gender Differences in Using Taboo Language.Swedish: Kristianstad University.

Risch, B. 1987.Women's Derogatory Terms for Men: That's Right, "Dirty" Words. Language in Society.

Sugiyono.2017. Metode Penelitian Kuantitatif dan R\&D. Bandung: Alfabeta CV.

Trudgill, P. 2000. Sociolinguistics: An Introduction to Language and Society. London: Oxford University Press.

Vingerhoets, Ad. 2013. Swearing : A Biopsychosocial Perspective. The Netherlands: Tilburg University.

Wardhaugh, Ronald. 2000. An Introduction to Sociolinguistics (Third edition). Oxford: Blackwell Publishers Ltd.

Wahyudi, Stefany. 2008. Types ad Functions of Taboo Words in Edmund White's A Boy's Own Story. Yogyakarta: Universitas Negeri Yogyakarta.

Wijana, I et al. 2006. Sosiolinguistik Kajian Teori dan Analisis. Yogyakarta: Pustaka Pelajar. 
Wulandari, Octavia.2017. The Use of Swear Words in Pewdiepie's Youtube Videos. Journal.

Makassar: UIN Aluddin Makassar. 